\title{
Anti-fibrotic effects of thalidomide on hepatic stellate cells and dimethylnitrosamine-intoxicated rats
}

\author{
Lee-Won Chong ${ }^{1,2}$, Yi-Chao $\mathrm{Hsu}^{3}$, Yung-Tsung Chiu ${ }^{4}$, Kuo-Ching Yang $^{2}$ \& \\ Yi-Tsau Huang ${ }^{3, *}$ \\ ${ }^{1}$ Graduate Institute of Clinical Medicine, School of Medicine, National Yang Ming University, Taipei, \\ Taiwan; ${ }^{2}$ Division of Hepatology and Gastroenterology, Department of Internal Medicine, Shin Kong Wu \\ Ho-Su Memorial Hospital, Taipei, Taiwan; ${ }^{3}$ Institute of Traditional Medicine, School of Medicine, National \\ Yang-Ming University, No. 155, Li-Nong Street, Sec. 2, Taipei, 112, Taiwan; ${ }^{4}$ Department of Medical \\ Research and Education, Taichung Veterans General Hospital, Taichung, Taiwan
}

Received 4 July 2005; accepted 25 November 2005

(c) 2006 National Science Council, Taipei

Key words: collagen, hepatic fibrosis, $\mathrm{NF \kappa B}, \alpha$-smooth muscle actin, thalidomide, transforming growth factor- $\beta 1$, tumor necrosis factor- $\alpha$

\section{Summary}

Tumor necrosis factor-alpha (TNF- $\alpha$ ) plays a central role in cellular necrosis, apoptosis, organ failure, tissue damage, inflammation and fibrosis. These processes, occurring in liver injury, may lead to cirrhosis. Thalidomide, $\alpha$-N-phthalidoglutarimide, $\left(\mathrm{C}_{13} \mathrm{H}_{10} \mathrm{~N}_{2}\right)_{4}$, has been shown to have immunomodulatory and anti-inflammatory properties, possibly mediated through its anti-TNF- $\alpha$ effect. In this study, we investigated the in vitro and in vivo effects of thalidomide on hepatic fibrosis. A cell line of rat hepatic stellate cells (HSC-T6) was stimulated with transforming growth factor- $\beta 1$ (TGF- $\beta 1$ ) or TNF- $\alpha$. The inhibitory effects of thalidomide on the $\mathrm{NF \kappa B}$ signaling cascade and fibrosis markers including $\alpha$-smooth muscle actin $(\alpha-$ SMA) and collagen, were assessed. An in vivo therapeutic study was conducted in dimethylnitrosamine (DMN)-treated rats, which were randomly assigned to 1 of 4 groups: vehicle $(0.7 \%$ carboxyl methyl cellulose, CMC), thalidomide (40 mg/kg), thalidomide $(200 \mathrm{mg} / \mathrm{kg})$, or silymarin $(50 \mathrm{mg} / \mathrm{kg})$, each given by gavage twice daily for 3 weeks starting after 1 week of DMN administration. Thalidomide (100-800 nM) concentration-dependently inhibited NFкB transcriptional activity induced by TNF- $\alpha$, including IKK $\alpha$ expression and I $\mathrm{B} \boldsymbol{B} \alpha$ phosphorylation in HSC-T6 cells. In addition, thalidomide also suppressed TGF- $\beta 1$ induced $\alpha$-SMA expression and collagen deposition in HSC-T6 cells. Fibrosis scores of livers from DMNtreated rats receiving high dose of thalidomide $(0.89 \pm 0.20)$ were significantly reduced in comparison with those of DMN-treated rats receiving vehicle $(1.56 \pm 0.18)$. Hepatic collagen contents of DMN rats were also significantly reduced by either thalidomide or silymarin treatment. Immunohistochemical double staining results showed that $\alpha$-SMA- and NFKB-positive cells were decreased in the livers from DMN rats receiving either thalidomide or silymarin treatment. In addition, real-time PCR analysis indicated that hepatic mRNA expressions of TGF- $\beta 1, \alpha$-SMA, collagen $1 \alpha 2$, TNF- $\alpha$ and iNOS genes were attenuated by thalidomide treatment. In conclusion, our results showed that thalidomide inhibited activation of HSC-T6 cells by TNF- $\alpha$ and ameliorated liver fibrosis in DMN-intoxicated rats.

*To whom correspondence should be addressed.: Fax: + 886-228225044; E-mail: huangyt@ym.edu. 
Abbreviations: $\alpha$-SMA - $\alpha$-smooth muscle actin; Col $1 \alpha 2$ - collagen $1 \alpha 2$; DMN - dimethylnitrosamine; G3PDH - glyceraldehyde-3-phosphate dehydrogenase; HSC - hepatic stellate cell; iNOS - inducible nitric oxide synthase; TGF- $\beta 1$ - transforming growth factor- $\beta 1$; TNF- $\alpha$ - tumor necrosis factor- $\alpha$

\section{Introduction}

Liver fibrosis is characterized by an excessive deposition of extracellular matrix (ECM) proteins and can ultimately lead to cirrhosis and organ failure [1]. The main causes of liver fibrosis include chronic viral hepatitis, alcohol abuse, autoimmune diseases and hereditary metabolic disorders. Activation of hepatic stellate cells (HSCs) has been implicated in the pathogenesis of liver fibrosis $[1,2]$. During the activation process, HSCs undergo phenotype transformation from vitamin-A-storing quiescent cells to myofibroblast-like activated cells. Activated HSCs are proliferative and fibrogenic, with accumulation of ECM, including $\alpha$-smooth muscle actin ( $\alpha$-SMA) and type I collagen [1-4]. A wealth of evidence suggests that a number of cytokines including transforming growth factor- $\beta 1$ (TGF- $\beta 1)$, platelet derived growth factor, and tumor necrosis factor-alpha $(\mathrm{TNF}-\alpha)$, are important activators of HSCs in the course of liver fibrogenesis [1-4].

Nuclear factor $\kappa \mathrm{B}(\mathrm{NF} \kappa \mathrm{B})$ is an essential transcription factor of a number of genes involved in immune, inflammatory, and growth responses. $\mathrm{NF \kappa \textrm {B }}$ is activated by various stimuli, including pro-inflammatory cytokines (e.g., TNF- $\alpha$ ), growth factors, viral proteins and DNA-damaging agents [5-7]. In most cells under normal conditions, NF $\kappa B$ exists in a latent state in the cytosol and is bound to inhibitory proteins including $I \kappa B \alpha$ that mask a nuclear localization signal. Cytokines such as TNF$\alpha$ activate $\mathrm{NF} \kappa \mathrm{B}$ signaling via the activation of the I $\kappa \mathrm{B}$-kinase (IKK) complex and subsequently phosphorylate and thereby degrade the $\mathrm{I} \kappa \mathrm{B} \alpha$ protein, releasing the cytosolic dimer p65-p50 to translocate into the nucleus to activate transcription of various genes including inducible nitric oxide synthase (iNOS) [8-11]. Several in vitro studies showed that HSC activation is associated with elevation of $\mathrm{NF \kappa B}$ activity [12-14]. In vivo, elevated levels of hepatic TNF- $\alpha$ occur in acute and chronic liver diseases, including fulminant hepatic failure, viral hepatitis and alcohol abuse $[15,16]$. Taken together, these observations suggest a critical role of $N F \kappa B$ in the activation of HSCs and an anti-TNF- $\alpha$ strategy to be potentially beneficial for treating liver fibrosis.

Thalidomide, $\alpha-N$-phthalidoglutarimide, $\quad\left(\mathrm{C}_{13}\right.$ $\left.\mathrm{H}_{10} \mathrm{~N}_{2}\right)_{4}$, initially was used as a sedative and anti-emetic during pregnancy but was withdrawn from the market due to its teratogenic effects. Despite its disastrous initial application, thalidomide subsequently has been shown to suppress TNF- $\alpha$ production by macrophages and other cell types such as activated T-cells and Langerhans cells [17-19]. To date, thalidomide has been therapeutically used for intractable diseases with pathogenesis involving TNF- $\alpha$, including graft vs. host disease, rheumatic arthritis, sarcoidosis, Crohn's disease, and ulcerative colitis [20-23]. The role of TNF- $\alpha$ in liver injury has been studied in several animal models. In alcohol-mediated toxicity, thalidomide prevents Kupffer cell sensitization and reduces liver injury [24]. Thalidomide has also been reported to ameliorate hepatic fibrosis in rat models induced by carbon tetrachloride, bile duct obstruction, and thioacetamide [25-27]. However, cellular mechanisms of action of thalidomide are yet unclear in these studies. The present study was therefore undertaken to investigate firstly the antifibrogenic effects of thalidomide, using in vitro assays in HSCs, and secondly conduct a therapeutic study in another rat model of hepatic fibrosis induced by dimethylnitrosamine.

\section{Materials and methods}

\section{HSC-T6 cell line}

In vitro study was performed in the HSC-T6 cell line, a generous gift of Prof. S.L. Friedman of the Mount Sinai School of Medicine (NY, USA). The HSC-T6 cell line is immortalized rat HSCs transfected with lipofectamine containing a cDNA in which the expression of the large $\mathrm{T}$-antigen of SV40 is driven by the Rous sarcoma virus promoter [28]. HSC-T6 cells were maintained in Waymouth medium (containing 10\% fetal bovine serum (FBS), pH 7.0) at $37^{\circ} \mathrm{C}$ in $5 \% \mathrm{CO}_{2} / 95 \%$ 
air. The cultures were passaged by trypsinization every 4th day and cells were plated in $150-\mathrm{mm}$ culture dishes at a density of $1 \times 10^{7}$ cells per dish in Waymouth medium and incubated under $5 \% \mathrm{CO}_{2}$ in air at $37^{\circ} \mathrm{C}$. Bioassay systems of the HSC-T6 cell line have been established in our laboratory [29].

\section{Transiently transfected cells and luciferase assays}

$\mathrm{NF \kappa B}$ luciferase assays were adapted from the method of Park et al. [30]. Briefly, HSCs $\left(10^{5}\right.$ cells/ well) were seeded on 24-well plates the day before transfection. Plasmid NFKB-Luc $(1 \mu \mathrm{g} /$ well $)$ (Strategene, La Jolla, CA) and pRL-SV40 $(0.2 \mu \mathrm{g} /$ well) (Promega, Madison. USA) were transfected into cells by lipofectamine (Invitrogen, Califonia,

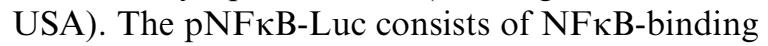
region, followed by the reporter gene firefly luciferase. Plasmid pRL-SV40 served as an internal control to normalize the transfection efficiency. After co-treatment with TNF- $\alpha$ and thalidomide for different time points $(3,6,9 \mathrm{~h})$ in $5 \% \mathrm{CO}_{2}$ incubator at $37^{\circ} \mathrm{C}$, cells were harvested and lysed in $100 \mu \mathrm{l}$ of lysis reagent. Twenty $\mu \mathrm{l}$ of cell lysate was then mixed with $100 \mu \mu$ of luciferin (the substrate of luciferase) right before luminescence detection. The luminescence, generated by luciferase activity, was measured with AutoLumat LB953 (Berthold Technologies, Bad Wildbad, Germany). All reagents for luciferase assays were purchased from Promega (Madison, USA).

Western blot analysis for in vitro $\alpha-S M A, I K K \alpha$ expression, $I \kappa B \alpha$ phosphorylation and $N F \kappa B$ translocation

HSCs $\left(5 \times 10^{6}\right)$ were seeded in medium containing $10 \%$ FBS. After $24 \mathrm{~h}$, cells were washed twice with phosphate buffer solution (PBS) and the medium was replaced by serum-free medium. Cells (in serum-free medium) were pre-exposed to TGF$\beta 1(1 \mathrm{ng} / \mathrm{ml})$ for $1 \mathrm{~h}$ and washed twice with PBS, then treated with thalidomide for $24 \mathrm{~h}$ in the study of $\alpha$-SMA protein expression. On the other hand, cells were stimulated with TNF- $\alpha(20 \mathrm{ng} / \mathrm{ml})$ for $20 \mathrm{~min}$ in $5 \% \mathrm{CO}_{2}$ incubator at $37^{\circ} \mathrm{C}$, and then treated with thalidomide for $60 \mathrm{~min}$ for the study of IKK $\alpha$ and phospho-I $\mathrm{B} \alpha$ protein expression. After treatments, cytoplasmic extracts containing $\alpha$-SMA, IKK $\alpha$, and phospho-I $\mathrm{B} \mathrm{B} \alpha$ proteins were prepared from cells using the extraction kit
(Chemicon, Temecula, CA) according to the manufacturer's instructions. In brief, cells were washed with cold PBS, scraped off the plates and transferred to a clean centrifuge tube. After centrifugation at $250 \times g$ for 5 min at $4{ }^{\circ} \mathrm{C}$, the supernatant was discarded. Five volumes of ice-cold cytoplasmic lysis buffer containing $0.5 \mathrm{mM}$ dithiothreitol and $1 / 1000$ dilution of proteinase inhibitor cocktail were added. The cell pellet was resuspended gently and the cell suspension centrifuged at $250 \mathrm{~g}$ for $5 \mathrm{~min}$ at $4^{\circ} \mathrm{C}$. The supernatant was collected as cytoplasmic fraction for the analysis of $\alpha$-SMA (as previously reported by us) [29], IKK $\alpha$ expression and $\mathrm{I} \kappa \mathrm{B} \alpha$ phosphorylation, according to the methods of Alpert and Vilèek [31] and Yang et al. [32]. Twenty $\mu \mathrm{g}$ of proteins in the cytoplasmic or nuclear fraction were separated on a $10 \%$ SDSPAGE and transferred onto Immobilon-PVDF (Millipore, Bedford, MA, USA) in a transfer buffer (6.2 $\mathrm{mM}$ boric acid, $\mathrm{pH} 8.0$ ). Blots were incubated initially with blocking buffer $(10 \mathrm{mM}$ Tris, $100 \mathrm{mM} \mathrm{NaCl}, 0.1 \%$ Tween 20 , and $5 \%$ bovine serum albumin (BSA)) for $1 \mathrm{~h}$ at room temperature, and then with specific primary antibodies against mouse $\alpha$-actin (Calbiochem-Novabiochem, San Diego, CA, USA), mouse IKK $\alpha$, mouse phosphor-IкB $\alpha$, mouse $\alpha$-tubulin (Santa Cruz Biotechnology, Santa Cruz, California, CA, USA). Primary antibodies had been diluted (1:100) with Tris-buffered saline-Tween 20 (TBS-T) containing $5 \%$ BSA and $0.01 \%$ sodium azide. After antibody incubation, the blots were washed with TBS-T for $1 \mathrm{~h}$ and incubated with anti-mouse IgG conjugated with horseradish peroxidase (Santa Cruz Biotechnology, Santa Cruz, California, CA, USA) for $1 \mathrm{~h}$ at room temperature. After washing of the secondary antibodies (1:2000) with TBS-T, immunodection was performed, using an enhanced chemiluminscence kit for Western blot detection (Amersham Pharmacia Biotech, Buckinghamshire, U.K.). Film exposure ranged from a few seconds to 5 min. Bands were quantified using Kodak Image Analysis Software (Rochester, NY, USA).

\section{Quantification of collagen deposition in cultured HSC-T6 cells and in the livers of DMN rats}

HSCs (in serum-free medium) were co-treated with TGF- $\beta 1(1 \mathrm{ng} / \mathrm{ml})$ and thalidomide for $24 \mathrm{~h}$. Cells were washed and collagen deposited in the wells was assayed using the Sircol collagen assay kit 
(Biocolor, Belfast, Nothern Ireland) according to the manufacturer's instructions and the method described by Williams et al. [33]. Unbound dye was removed by washing and the bound complex dissolved in $0.5 \%$ sodium hydroxide. Collagen was quantitated by spectrophotometry at $540 \mathrm{~nm}$ and results were expressed as percentage of the untreated controls.

A portion of liver tissue was homogenized in acetic acid $(0.5 \mathrm{M})$ at $4{ }^{\circ} \mathrm{C}$ using an ULTRA TURRAX $^{\circledR}$ homogenizer (Ika Labotechnik, Staufen, Germany). The fraction of insoluble collagen after acid extraction, composed of crosslinked collagen, was then heated at $80^{\circ} \mathrm{C}$ for $60 \mathrm{~min}$ for conversion into soluble gelatin. The gelatin contents of the acid extracts were assayed using the Sircol collagen assay kit (Biocolor, Belfast, Nothern Ireland) according to the manufacturer's instructions and the method described by Shiba et al. [34] and in our previous paper [29].

\section{Measurement of cytotoxicity to HSCs (MTT assay)}

The assay of reduction of 3-(4,5-dimethylthiazol2-yl)-2,5-diphenyltetrazolium bromide (MTT) was used to evaluate the potential of thalidomide cytotoxicity. HSCs were incubated in 24-well plates containing Waymouth medium (FBS-free) with or without thalidomide at different concentrations for $24 \mathrm{~h}$ at $37^{\circ} \mathrm{C}$. During the last hour, the cells were incubated with minimum essential medium containing $0.1 \mathrm{mg} / \mathrm{ml}$ MTT. The medium was aspirated, and the formazan particle was dissolved with DMSO. $\mathrm{A}_{540}$ absorption intensity was measured using enzyme-linked immunosorbent assay reader, according to the method of Hansen et al. [35]. Relative cell viability was determined by the amount of MTT converted to the insoluble formazan salt. The optical density of the formazan formed in the control cells was taken as $100 \%$ viability.

\section{Hepato-fibrotic animals}

Hepatic fibrosis was induced by DMN administration in male Sprague-Dawley rats and we have recently documented changes in molecular and cell biological parameters related to fibrosis in these rats $[29,36]$. DMN $(5 \mathrm{mg} / \mathrm{kg})$ was injected intraperitoneally for 3 consecutive days per week for
4 weeks, according to the method of Jezequel et al. [37]. DMN (1 g/ml) was purchased from Sigma Chemical Co. (St. Louis, MO, USA) and diluted 100 folds in saline with a final concentration of $10 \mathrm{mg} / \mathrm{ml}$ before injection. Control rats were injected with saline alone. Rats were maintained on a standard rat pellet diet and tap water ad libitum. Animal studies were approved by the Institutional Animal Care and Use Committee of the University and conducted humanely, in accordance with the Guide for the Care and Use of Laboratory Animals [National Academic Press, USA, 1996]. There were five groups of rats: (a) control rats receiving $0.7 \%$ carboxyl methyl cellulose (CMC), (b) DMN rats receiving 0.7\% CMC, (c) DMN rats receiving silymarin $(50 \mathrm{mg} / \mathrm{kg}$, mixed with $0.7 \% \mathrm{CMC}$ ), (d) DMN rats receiving thalidomide $(40 \mathrm{mg} / \mathrm{kg})$, and (e) DMN rats receiving thalidomide $(200 \mathrm{mg} / \mathrm{kg})$, each given by gavages twice daily for 3 weeks starting at 1 week after DMN administration. Four weeks after DMN or saline injection, the rats were examined for the parameters listed below. On the day of measurement, venous blood was withdrawn from each rat under anesthesia, and thereafter the rat was sacrificed by $\mathrm{KCl}$ injection to remove the liver for homogenization and biochemical analysis.

\section{Histopathological examination}

For morphometric studies, the liver fragments were taken from the left lobe of each rat. Liver specimens were preserved in $4 \%$ buffered paraformaldehyde and dehydrated in a graded alcohol series. Following xylene treatment, the specimens were embedded in paraffin blocks, cut into 5 - $\mu \mathrm{m}$ thick sections and placed on glass slides. The sections were then stained with picro-sirius red for collagen distribution [38]. A numerical scoring system for histologically assessing the extent of fibrosis was adapted from the formula of Scheuer [39], with minor modification [29]. Briefly, fibrosis was staged as: 0: no fibrosis; stage 1: enlarged, fibrous portal tracts; stage 2: periportal or portalportal septa, but intact architecture; stage 3: fibrosis with architectural distortion; stage 4: probable or definite cirrhosis. Additionally, hepatocyte necrosis or degeneration severity was also graded as: 0, no hepatocyte necrosis or degeneration; grade 1, focal necrosis or degeneration of hepatocytes (mild, lesion $\leq 3$ ); grade 2 , multifocal 
necrosis or degeneration of hepatocytes (moderate, lesion $>3$ ); grade 3, locally extensive or diffuse necrosis or degeneration of hepatocytes (severe). The liver scoring examination was performed by a pathologist (Y.-T. C.) who was blinded to rats' treatment assignment. Fibrosis and hepatocyte scores were given after the pathologist had examined throughout three different areas in the tissue slide for each rat.

\section{Immuno-fluorescence staining $(\alpha-S M A$ and $N F \kappa B$ p65 double staining)}

Tissue sections were incubated with monoclonal mouse anti-human SMA antibody (1:500 dilution, Dako) overnight at $37^{\circ} \mathrm{C}$ and then with rhodamine-conjugated donkey anti-mouse $\mathrm{IgG}$ antibody (Jackson ImmunoResearch Laboratories Inc., USA) for $1 \mathrm{~h}$ at $37^{\circ} \mathrm{C}$. All the sections were subsequently incubated with fluorescein conjugated anti-rat NFkB p65 antibody (1:500 dilution, Santa Cruz Biotechnology, Santa Cruz, California, CA, USA) for $1 \mathrm{~h}$ at $37^{\circ} \mathrm{C}$. All sections were observed under a laser confocal microscopy (TCSSP2, Leica, Wetzlar, Germany). The pictures of fluorescein-isothiocyanate images and those of rhodamine images were merged using Leica image analysis software. Double staining techniques of $\alpha$-SMA and NFкB p65 were adapted from the report of Kitamura and Ninomiya [40].

\section{Western blot analysis for hepatic $\alpha$-SMA expression}

Cytoplasmic extracts containing $\alpha$-SMA protein were prepared from hepatic tissues using the extraction kit (Chemicon, Temecula, CA) according to the manufacturer's instructions. The procedures of Western blots have been reported by us $[29,36]$ and described above.

\section{Biochemical analysis of plasma}

Blood samples were collected $(6 \mathrm{ml}$ each from the femoral vein) and immediately centrifuged at $1300 \times g$ at $4{ }^{\circ} \mathrm{C}$, and plasma was kept at $-20{ }^{\circ} \mathrm{C}$ for liver function tests. Alanine transaminase (ALT) and aspartate transaminase (AST) levels were measured using a colorimetric analyzer (Dri-Chem 3000, Fuji Photo Film Co, Tokyo, Japan), as we described previously [29].
Quantitative real-time PCR for the analysis of transcripts of $\alpha-S M A, T G F-\beta 1$, collagen $1 \alpha 2$, $T N F-\alpha$ and iNOS genes

Total RNA was isolated from hepatic tissues by the method of Chomczynski and Sacchi [41]. For cDNA synthesis, $1 \mu \mathrm{g}$ of total RNA was reversetranscribed in a $30 \mu \mathrm{l}$ of reaction mixture containing $10 \mu \mathrm{M}$ dNTP mix, $500 \mu \mathrm{g} / \mu \mathrm{l}$ oligo(dT), 0.2 $\mu \mathrm{M}$ dithiothreitol, 40 units of RNase inhibitor, 200 units of M-MLV reverse transcriptase, and $5 \times$ buffer (with $1.5 \mathrm{mM} \mathrm{MgCl}_{2}$ ) (Invitrogen, Califonia, USA). The reaction mixture was incubated at $37^{\circ} \mathrm{C}$ for $60 \mathrm{~min}$ and then denatured at $65^{\circ} \mathrm{C}$ for $10 \mathrm{~min}$. In the study, we used two different methods of quantative PCR: (I) SyBR Green method for the expressions of G3PDH, TGF- $\beta 1$, and $\alpha$-SMA. SyBR Green, a doublestranded DNA binding dye, was used for the fluorescent detection of DNA generated during the PCR. The PCR reaction was performed in a total volume of $20 \mu \mathrm{l}$ with $0.4 \mathrm{pmol} / \mu \mathrm{l}$ of each primer, and $2 \times$ SyBR Green PCR master mix (Applied Biosystems, Foster City, CA, USA); $1 \mu \mathrm{l}$ cDNA corresponding to $100 \mathrm{ng}$ of total RNA was used as template. The primer sequences for PCR amplification $\left(\alpha\right.$-SMA forward primer: $5^{\prime}$-TTC GTT ACT ACT GCT GAG CGT GAG A-3', reverse primer: 5'-AAA GAT GGC TGG AAG AGG GTC-3'; TGF- $\beta 1$ forward primer: $5^{\prime}$-TAT AGC AAC AAT TCC TGG CG-3', reverse primer: 5'-TGC TGT CAC AGG AGC AGTG-3'; G3PDH forward primer: 5'-AGC CCA GAA CAT CAT CCC TG3', reverse primer: 5'-CAC CAC CTT CTT GAT GTC ATC-3') were according to our previous report [29]. (II) The Taqman ${ }^{\circledR}$ PCR Core reagent kit (PE Applied Biosystems, Foster City, CA, USA) was used according to the manufacturer's protocol for the expressions of G3PDH, iNOS, collagen $1 \alpha 2$. Specific primers and probe for G3PDH, TNF- $\alpha$, iNOS, and collagen $1 \alpha 2$ were synthesized by PE Applied Biosystems. For each sample tested, PCR reaction was carried out in a $50-\mu \mathrm{l}$ volume containing $1 \mu \mathrm{l}$ of cDNA reaction (equivalent to $50 \mathrm{ng}$ of template RNA) and 2.5 units of AmpliTaq Gold. Oligonucleotide primers and fluorogenic probe were added to a final concentration of $100 \mathrm{nM}$ each. The amplification step consisted of 60 cycles of $94{ }^{\circ} \mathrm{C}$ for $45 \mathrm{~s}$, $58^{\circ} \mathrm{C}$ for $45 \mathrm{~s}$, and $65^{\circ} \mathrm{C}$ for $1 \mathrm{~min}$. 


\section{Chemicals and drugs}

Waymouth's MB 752/1 medium and FBS were from Gibco BRL (Gaithersburg, MD). 3-[4,5-Dimethylthiazol-2-yl]-2,5-diphenyltetrazolium bromide (MTT) and dimethyl sulfoxide were purchased from Sigma Chemical (St. Louis, MO). $\alpha$-SMA antibody was from Calbiochem (Darmstadt, Germany). Thalidomide was from TTY Biopharm Company Ltd. (Taipei, Taiwan.). For the in vitro study, thalidomide was dissolved in dimethyl sulfoxide (DMSO) to make a $50 \mathrm{mg}$ per $\mathrm{ml}$ stock solution. For the in vivo study, thalidomide was mixed with $0.7 \%$ carboxyl methyl cellulose (CMC). Silymarin and other chemicals were from Sigma Chemical Co (St. Louis, MO, USA). Silymarin was also mixed with $0.7 \%$ CMC for in vivo administration.

\section{Data analysis}

Data are expressed as the mean $\pm \mathrm{SEM}$. One-way analysis of variance (ANOVA) was used for comparison of biochemical and molecular parameters. Statistical significance was accepted at $p<0.05$. A non-parametric method (the Dunn procedure under the Kruskal-Wallis test) was used for multiple pairwise comparisons between groups for the histological grades of fibrosis. Statistical significance was accepted at $p<0.05$.

\section{Results}

In vitro effects of thalidomide on HSC-T6 cells

Inhibition of collagen deposition and $\alpha-S M A$ expression in TGF- $\beta 1$-treated HSC-T6 cells by thalidomide

TGF- $\beta 1$ stimulated collagen deposition and $\alpha$-SMA secretion in HSC-T6 cells (Figure 1a and b). TGF- $\beta 1$ (1 ng/ml)-stimulated collagen deposition was $151 \pm 12 \%$ of controls, and thalidomide (100-800 nM) concentration-dependently reduced this percentage, with higher concentrations achieving significant reduction (Figure 1a). The ratio of $\alpha$-SMA:tubulin protein expression increased from $0.15 \pm 0.01$ at the baseline to $0.34 \pm 0.03$ after TGF- $\beta 1$ ( $1 \mathrm{ng} / \mathrm{ml})$ stimulation. This ratio was significantly reduced to $0.15 \pm 0.02$ by thalidomide $(800 \mathrm{nM})$ (Figure 1b). The inhibitory effect of thalidomide on
TGF- $\beta 1$-treated HSC-T6 cells was not due to its cytotoxicity (Figure 1c).

\section{Inhibition of collagen deposition and collagen $1 \alpha 2$ gene expression in TNF- $\alpha$-treated HSC-T6 cells by thalidomide}

In HSC-T6 cells, TNF- $\alpha(20 \mathrm{ng} / \mathrm{ml})$-stimulated collagen deposition was $151 \pm 8 \%$ of controls $(p<0.05)$, and thalidomide $(800 \mathrm{nM})$ significantly reduced this percentage to $111 \pm 9 \%$ of controls $(p<0.05)$. The mRNA expression level of collagen 1 $\alpha 2$ was increased by TNF- $\alpha$ at $20 \mathrm{ng} / \mathrm{ml}(198 \pm 15 \%$ of baseline, $p<0.01)$, and thalidomide at $800 \mathrm{nM}$ significantly inhibited TNF- $\alpha$-stimulated collagen 1 $\alpha 2$ mRNA expression to $105 \pm 18 \%$ of baseline $(p<0.01)$. These results suggested fibrogenic activation of HSCs by TNF- $\alpha$, and such fibrogenic activation of HSCs was significantly inhibited by thalidomide. In contrast, TNF- $\alpha(20 \mathrm{ng} / \mathrm{m} 1)$ did not upregulate the mRNA expression of TGF- $\beta 1$ $(134 \pm 23 \%$ of baseline, $p=0.118)$ in HSC-T6 cells.

\section{Suppression of $N F \kappa B$ transcription activity by thalidomide}

TNF- $\alpha(20 \mathrm{ng} / \mathrm{ml})$ stimulated NF $\kappa$ B in HSC-T6 cells, with luciferase activity being $175 \pm 36 \%$, $198 \pm 20 \%$ and $194 \pm 66 \%$ of controls, respectively after treatment for 3, 6, and $9 \mathrm{~h}$ (Figure 2a). Thalidomide (100-800 nM) attenuated the NFкB activity induced by TNF- $\alpha$ at 3 and 6 h. The ability of thalidomide to inhibit TNF- $\alpha$-stimulated NF $\kappa B$ activity was transient, as suppression was not significant at $9 \mathrm{~h}$ (Figure 2a).

Inhibition of IKK $\alpha$ expression and $I \kappa B \alpha$ phosphorylation in TNF- $\alpha$-stimulated HSC-T6 cells by thalidomide

Following TNF- $\alpha$ stimulation for $20 \mathrm{~min}$, both IKK $\alpha$ expression and I $\mathrm{B} \alpha$ phosphorylation were significant increased. This implied that IKK $\alpha$ activity was significantly induced by $\mathrm{TNF}-\alpha$ treatment. IKK $\alpha$ expression and I $\mathrm{I} \mathrm{B} \alpha$ phosphorylation were both concentration-dependently reduced by thalidomide treatment (Figure 2b and $\mathrm{c}$ ).

\section{In vivo effects of thalidomide on DMN rats}

\section{General features}

The body weight of DMN rats was significantly lower than that of control rats (Table 1). 

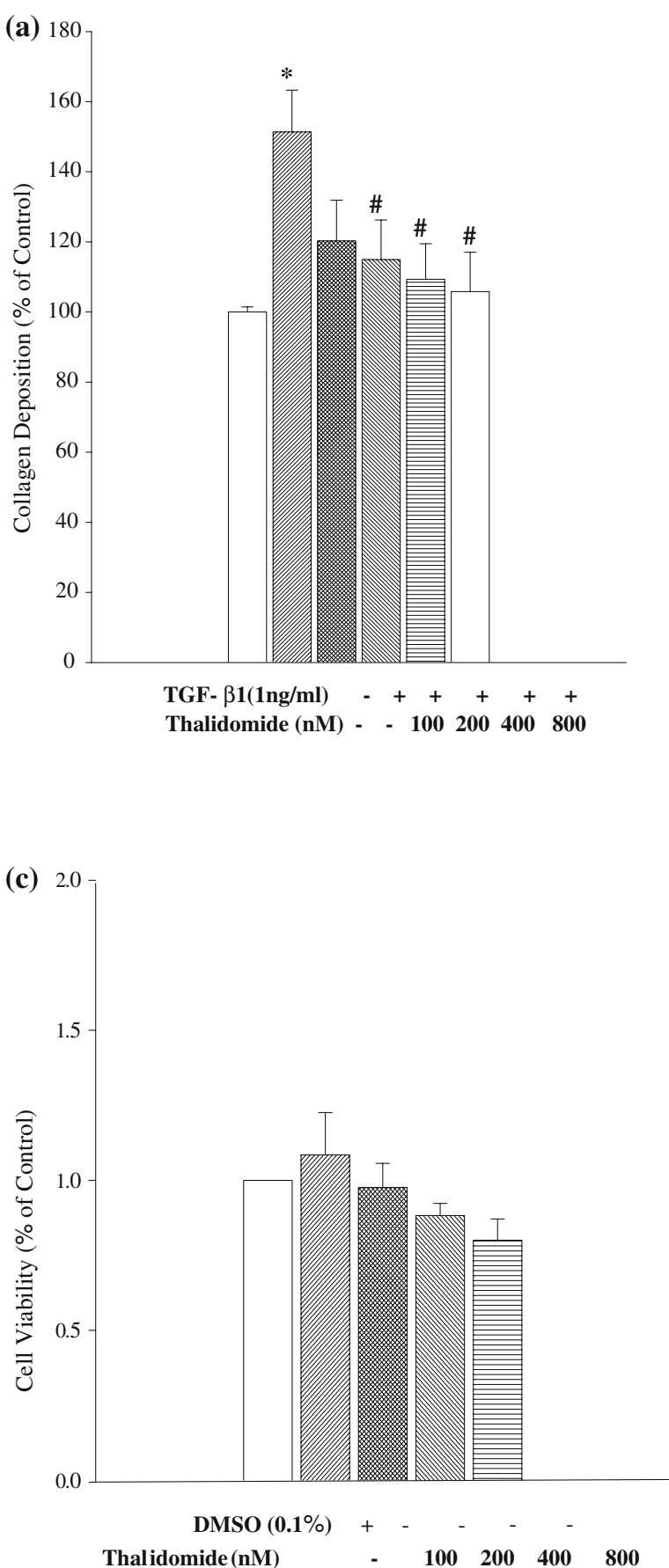

(b) TGF- $\beta 1$ (1ng/ml) - + + + +

Thalidomide $(\mathrm{nM})-\quad-\quad 100 \quad 200 \quad 400800$
DMSO $(0.1 \%)+\quad+\quad-\quad-\quad-\quad-$

$\alpha-$ SMA

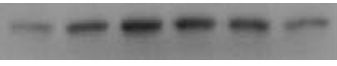

42KD

$\alpha$-tubulin
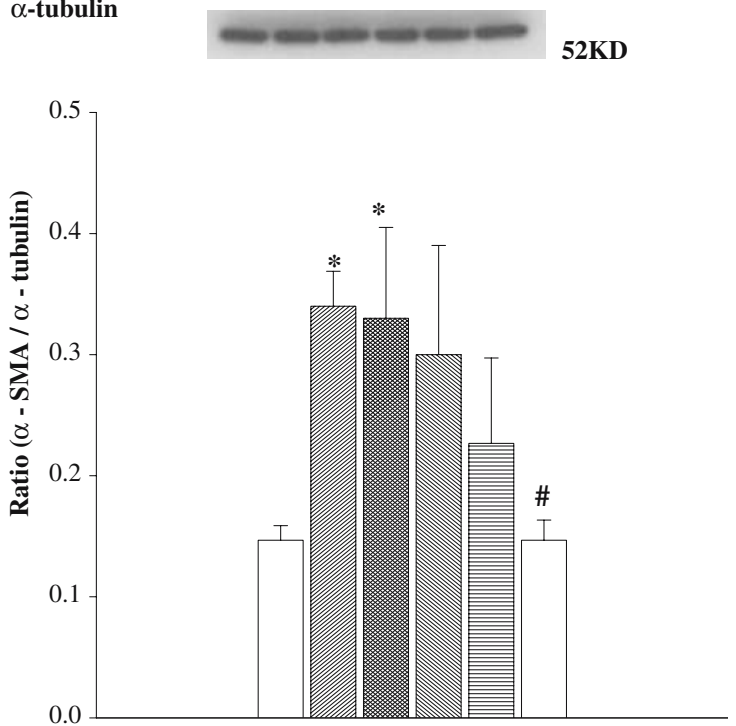

Figure 1. (a) Effects of thalidomide on collagen deposition by HSC-T6 cells after TGF- $\beta 1$ stimulation for $24 \mathrm{~h}$. Collagen deposition by HSC-T6 cells was quantified by sircol collagen assay. ${ }^{*} p<0.05$ vs. Control; ${ }^{*} p<0.05$ vs. TGF- $\beta 1$ alone, $(n=3)$. (b) Thalidomide reduced the protein expression of $\alpha$-SMA induced by TGF- $\beta 1(1 \mathrm{ng} / \mathrm{ml})$ in HSC-T6 cells. Representative results from three independent experiments are shown here. ${ }^{*} p<0.05$ vs. Control; ${ }^{*} p<0.05$ vs. TGF- $\beta 1$ alone. (c) Effects of thalidomide on cell viability of HSC-T6 cells at $24 \mathrm{~h}$ after treatments $(n=3)$. 


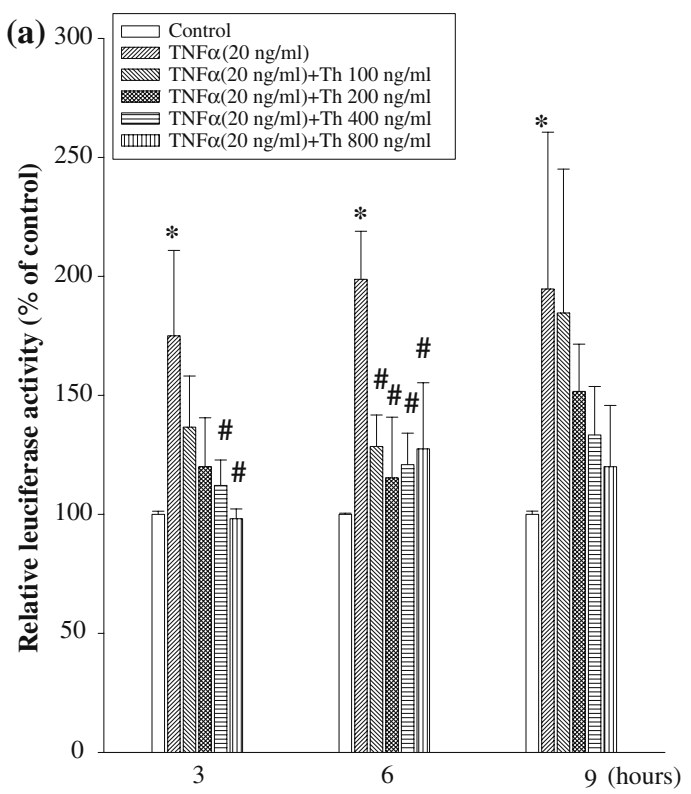

(b) TNF- $\alpha$ (20ng/ml) $\quad-\quad+\quad+++$

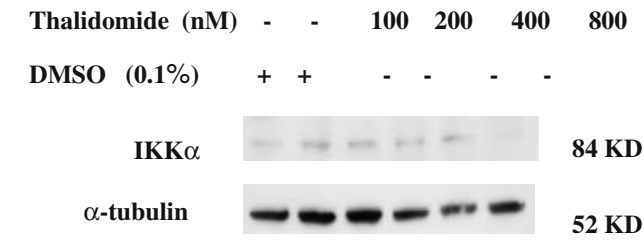

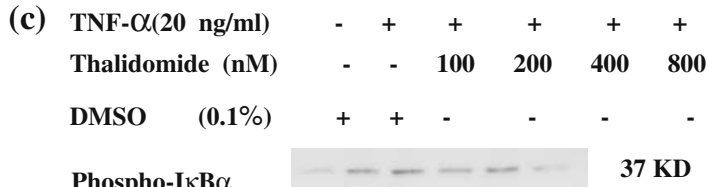
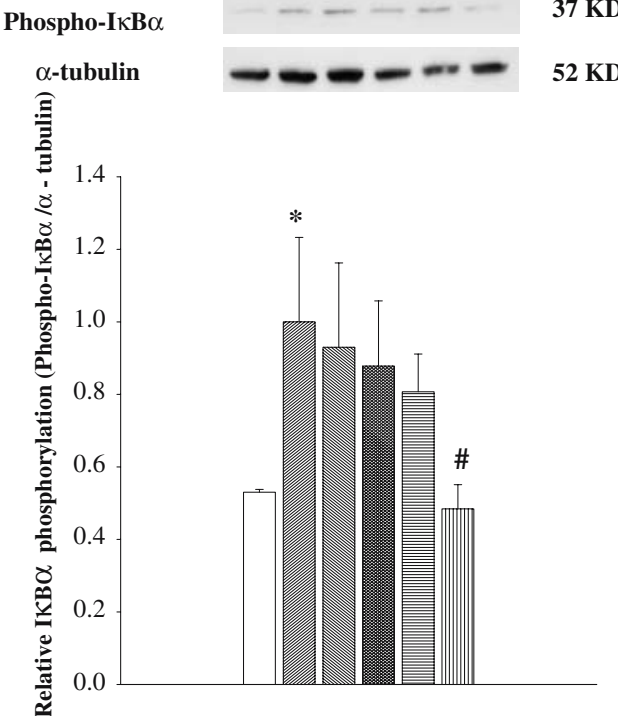

Figure 2. (a) Effects of thalidomide (Th) on TNF- $\alpha$-induced $\mathrm{NF} \kappa \mathrm{B}$ transcriptional activity in HSC-T6 cells at 3,6 and $9 \mathrm{~h}$ after treatment $(n=3)$. (b) Effects of thalidomide on TNF- $\alpha$-induced IKK $\alpha$ expression in cytoplasmic extracts of HSC-T6 cells. (c) Effects of thalidomide on TNF- $\alpha$-induced I $\kappa \mathrm{B} \alpha$ phosphorylation in cytoplasmic extracts of HSC-T6 cells. Representative results from three independent experiments are shown here. ${ }^{*} p<0.05$ vs. control; ${ }^{\#} p<0.05$ vs. TNF- $\alpha$ alone.

Administration of silymarin or thalidomide did not increase the body weight in DMN treated rats. DMN rats also displayed a sickened appearance, including less vigorous movements and less smooth fir. Besides, DMN rats showed a decrease in liver weight compared with control 
Table 1. General profiles in control rats and dimethylnitrosamine (DMN)-induced fibrotic rats receiving thalidomide, silymarin or vehicle treatment.

\begin{tabular}{lccccc}
\hline Group & Control & DMN-vehicle & DMN-Sil $(50 \mathrm{mg} / \mathrm{kg})$ & DMN-Th $(40 \mathrm{mg} / \mathrm{kg})$ & DMN-Th $(200 \mathrm{mg} / \mathrm{kg})$ \\
\hline BW (g) & $457 \pm 8$ & $384 \pm 10^{* *}$ & $379 \pm 12^{* *}$ & $387 \pm 3^{* *}$ & $383 \pm 6^{* *}$ \\
LW (g) & $14.1 \pm 0.7$ & $12.3 \pm 0.7^{*}$ & $12.1 \pm 0.6^{*}$ & $13.5 \pm 0.4$ & $14.8 \pm 0.4^{\# \#}$ \\
SW (g) & $0.90 \pm 0.04$ & $1.30 \pm 0.06^{* *}$ & $1.32 \pm 0.10^{* *}$ & $1.42 \pm 0.06^{* *}$ & $1.39 \pm 0.06^{* *}$ \\
AST (U/l) & $78 \pm 5$ & $158 \pm 22^{* *}$ & $160 \pm 25^{* *}$ & $110 \pm 11^{\#}$ & $104 \pm 11^{\# \#}$ \\
ALT (U/l) & $31 \pm 2$ & $108 \pm 13^{* *}$ & $105 \pm 6^{* *}$ & $83 \pm 6^{* *}$ & $87 \pm 10^{* *}$ \\
Collagen (mg/g liver) & $5.92 \pm 0.54$ & $8.08 \pm 0.53^{*}$ & $5.18 \pm 0.38^{\# \#}$ & $6.37 \pm 0.82^{\#}$ & $4.98 \pm 0.52^{\# \#}$ \\
\hline
\end{tabular}

Th, thalidomide; Sil, silymarin; BW, body weight; LW, liver weight; SW, spleen weight; AST, aspartate transaminase; ALT, alanine transaminase; collagen, Collagen content (mg/g liver dry weight). Data are expressed as the mean \pm SEM. The number of rats in each column is $9 .{ }^{*} p<0.05,{ }^{* *} p<0.01$ vs. control group, ${ }^{\#} p<0.05,{ }^{\#} p<0.01$ vs. DMN group.

rats. High-dose thalidomide treatment $(200 \mathrm{mg} /$ $\mathrm{kg}$ ) prevented this decrease in liver weight (Table 1).

\section{Plasma biochemistry}

DMN rats showed significantly higher plasma ALT and AST levels compared with control rats, indicating hepatic injury. Plasma AST levels in DMN rats were significantly decreased by both low-dose and high-dose treatment of thalidomide (Table 1). This result suggested that thalidomide ameliorated hepatic injury in DMN rats.

\section{Histological examination and hepatic collagen content}

Histological examination of livers from DMN rats revealed the following changes: increase and expansion of fibrous septa and loss of hepatocytes (multifocal necrosis of hepatocytes and focal degeneration of hepatocytes), compared with control rats. Collagen fibers, as stained by Sirius red, were more distinctly deposited in the liver of DMN rats as compared with control rats. Treatment with thalidomide or silymarin decreased collagen deposition (Figure 3a). As shown in Table 2, fibrosis scores of livers from DMN rats were significantly higher than control rats. Fibrosis scores were decreased in DMN rats treated with high-dose thalidomide compared with vehicle. Hepatocyte necrosis scores were reduced in DMN rats treated with high-dose thalidomide and silymarin, compared with vehicle. Hepatocyte degeneration scores were also attenuated only in the livers of DMN rats receiving high-dose thalidomide compared with vehicle.
As shown in Table 1, hepatic collagen contents were significantly increased in DMN rats compared with control rats, suggesting abundant accumulation of collagen in the liver of DMN rats. Hepatic collagen contents were significantly decreased with treatment of low- and high-dose thalidomide, or silymarin, suggesting that thalidomide and silymarin ameliorated hepatic collagen deposition in DMN rats. Hepatic collagen contents in DMN rats were reduced by 21 and $38 \%$ with low- and high-dose thalidomide, respectively, and by $36 \%$ with silymarin.

\section{Immuno-fluorescence double staining for $a-S M A$ and $N F \kappa B$}

In the immuno-staining for $\alpha$-SMA (red), $\alpha$-SMApositive cells (activated HSCs) were observed in the fibrous septa, portal tracts and sinusoids of the livers from DMN rats (Figure $3 b$ ). In double staining for $\alpha$-SMA (red) and NFкB (green), we observed $\mathrm{NF} \kappa \mathrm{B}$ translocated into the nucleus of $\alpha$-SMA-positive cells (activated HSCs), but not hepatocytes. Moreover, the $\alpha$-SMA-positive cells with $\mathrm{NF} \kappa \mathrm{B}$ nuclear translocation were also accumulated in the fibrous septa and portal tracts of the fibrotic livers. The $\alpha$-SMA-positive cells with $\mathrm{NF} \kappa \mathrm{B}$ nuclear translocation in DMN rats were reduced with the treatment of low- and high-dose thalidomide, and with silymarin (Figure 3b).

\section{Detection of $\alpha$-SMA protein in liver tissues}

Figure 4 shows that $\alpha$-SMA protein expression was increased significantly in the liver tissues of DMN rats compared with control rats, as detected by Western blot analysis. Treatment 


\section{(A)}
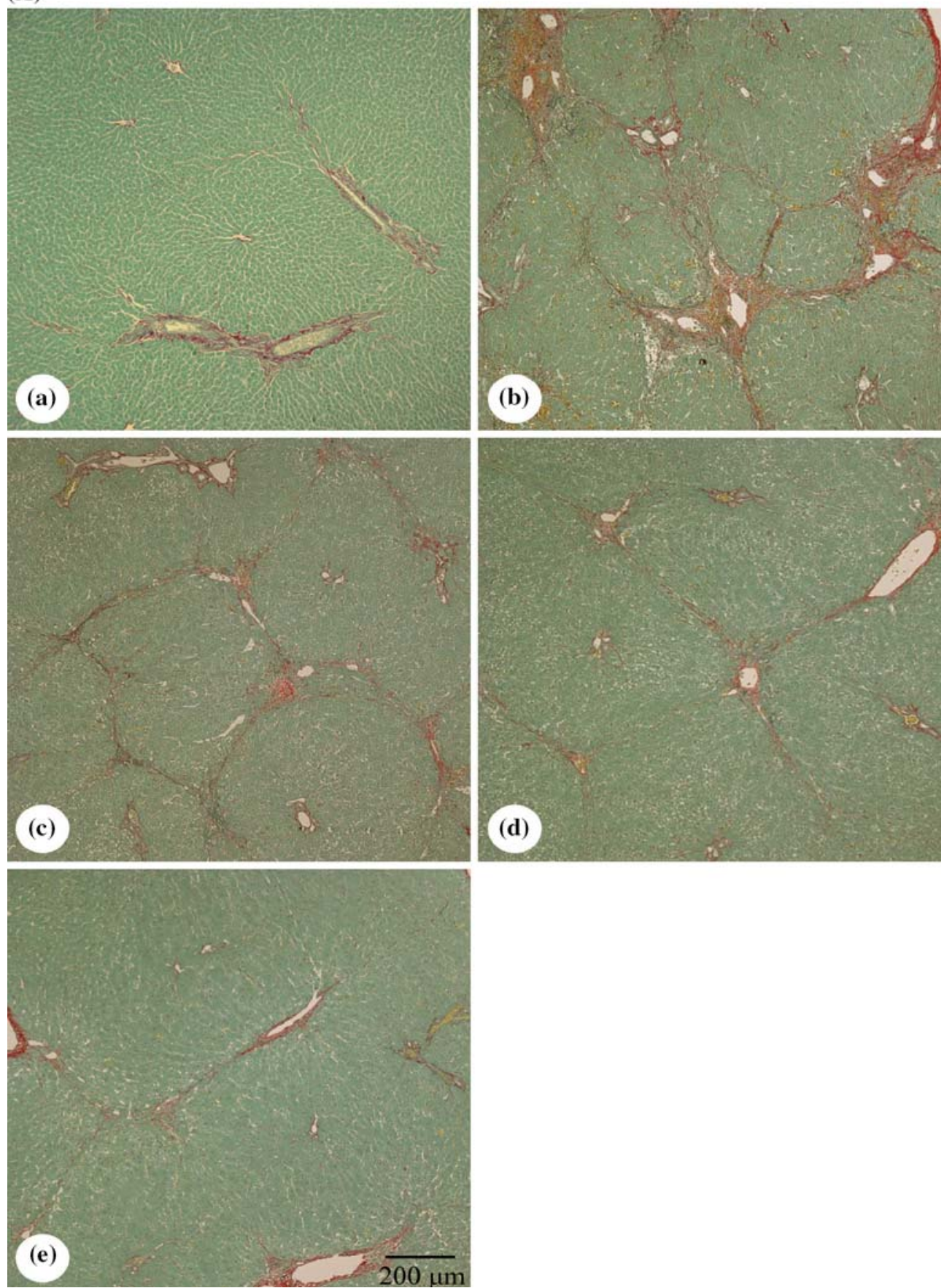

Figure 3. (a) Histological examination of liver sections in control and dimethylnitrosamine (DMN)-treated rats. Representative liver sections were obtained from control rats (a), DMN rats receiving vehicle (b), DMN rats receiving $50 \mathrm{mg} / \mathrm{kg}$ silymarin (c), DMN rats receiving 40-mg $/ \mathrm{kg}$ thalidomide, (d), and DMN rats receiving 200-mg/kg thalidomide (e). Sections were stained with Sirius red. Scale bar $=200 \mu \mathrm{m}$. (b) Double immunofluorescence staining was performed with anti- $\alpha$-SMA IgG (red) and an anti$\mathrm{NF} \kappa \mathrm{B}$ (p65) IgG (green). Scale bar $=50 \mu \mathrm{m}$. The pictures of fluorescein-isothiocyanate images and those of rhodamine images were merged by using Leica image analysis software. 
(B) Phase

(a)

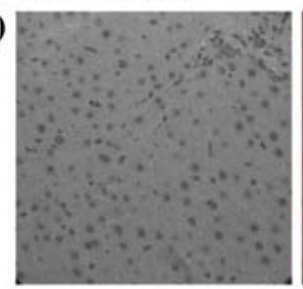

(b)

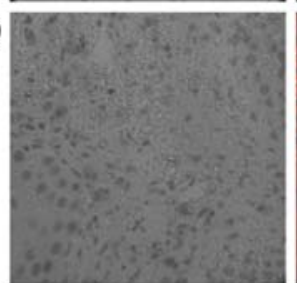

(c)

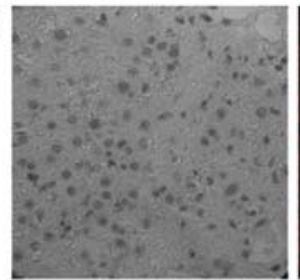

(d)

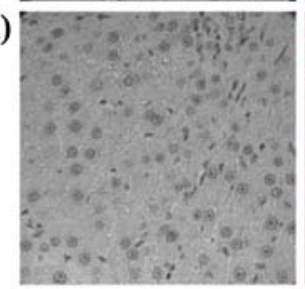

(e)

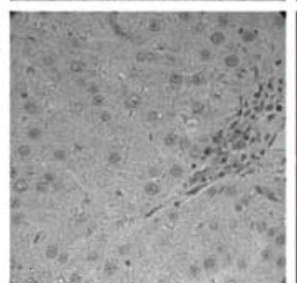

$\alpha$-SMA
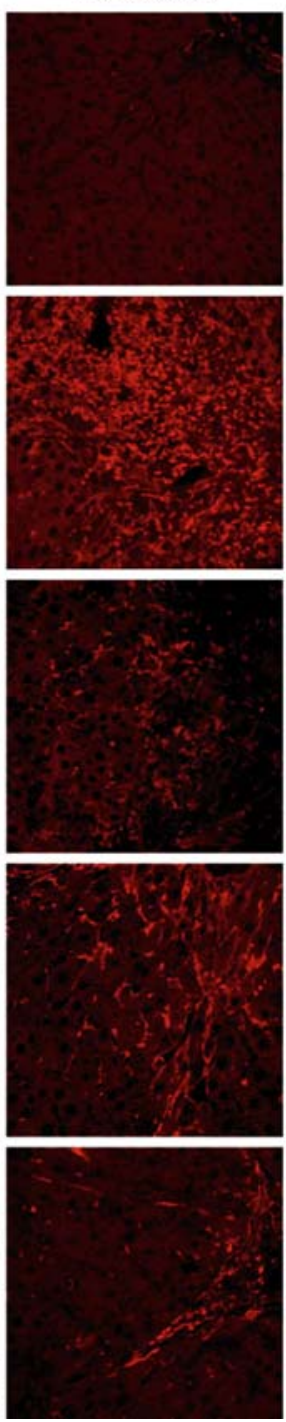

NFאB
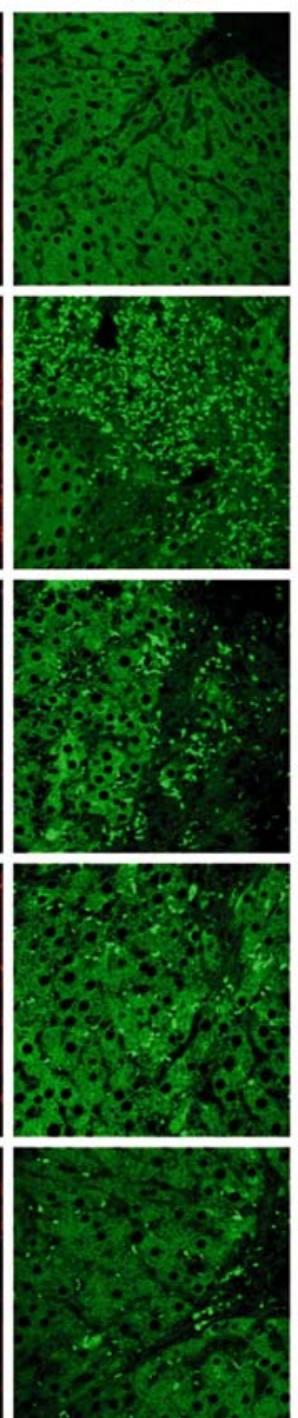

Merge
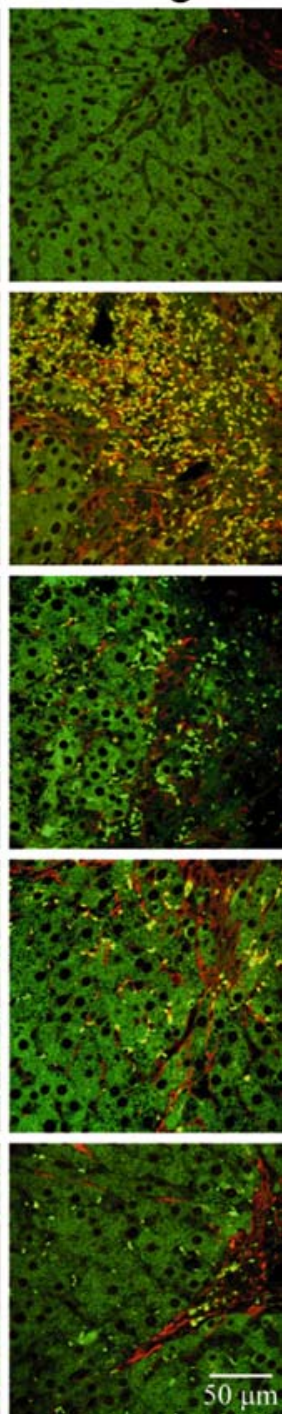

Figure 3. Continued.

Table 2. Fibrosis scores in control rats and dimethylnitrosamine (DMN)-induced fibrotic rats receiving thalidomide, silymarin or vehicle treatment.

\begin{tabular}{llllll}
\hline Group & Control & DMN-vehicle & DMN-Sil (50 mg/kg) & DMN-Th (40 mg/kg) & DMN-Th (200 mg/kg) \\
\hline Fibrosis score & $0 \pm 0$ & $1.56 \pm 0.18^{* *}$ & $1.25 \pm 0.16^{* *}$ & $1.56 \pm 0.29^{* *}$ & $0.89 \pm 0.20^{*, \#}$ \\
Hepatocyte necrosis & $0 \pm 0$ & $1.89 \pm 0.20^{* *}$ & $1.00 \pm 0.27^{*, \#}$ & $1.33 \pm 0.29^{*}$ & $0.78 \pm 0.32^{*, \#}$ \\
Hepatocyte degeneration & $0 \pm 0$ & $1.56 \pm 0.24^{* *}$ & $1.62 \pm 0.42^{*}$ & $0.89 \pm 0.26^{*}$ & $0.22 \pm 0.44^{\#}$ \\
\hline
\end{tabular}

Th, thalidomide; Sil, silymarin; data are expressed as the mean \pm SEM. The number of rats in each column is 9 . ${ }^{*} p<0.05, * * p<0.01$ vs. control group; ${ }^{\#} p<0.05,{ }^{\#} p<0.01$ vs. DMN group. 
$\alpha$-SMA

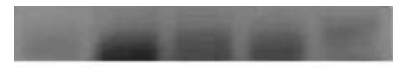

$42 K D$

$\alpha$-tubulin

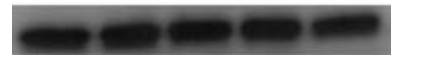

52KD

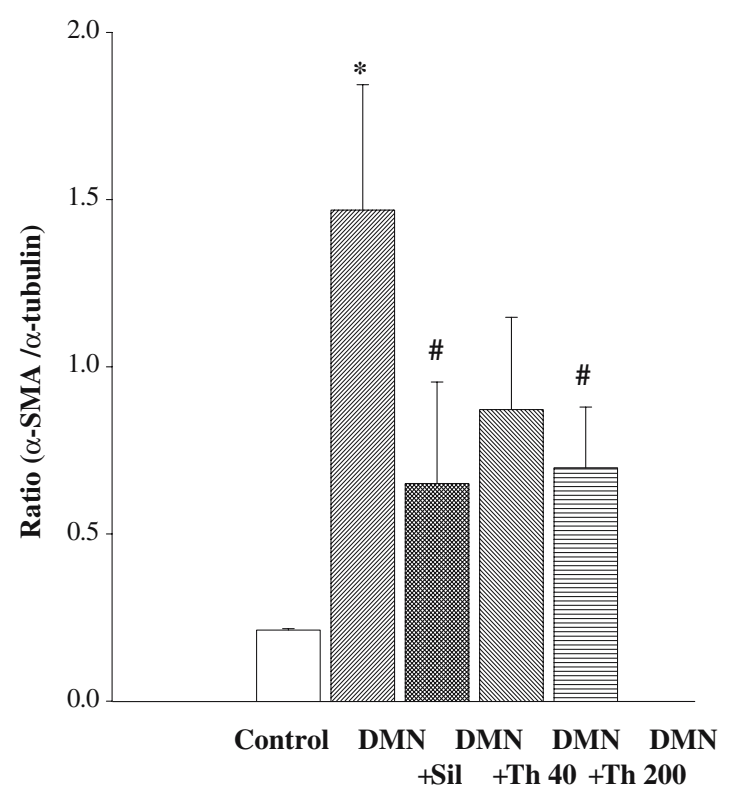

Figure 4. Thalidomide (Th) and silymarin (Sil) treatment reduced the protein expression of $\alpha$-SMA in the cytoplasmic extracts of liver tissues in DMN rats. The number of rats in each column is $8 .{ }^{*} p<0.05$ vs. the control group; ${ }^{\#} p<0.05$ vs. the DMN group receiving vehicle.

with high-dose thalidomide or silymarin reduced $\alpha$-SMA protein expression significantly.

Analysis of transcripts of a-SMA, TGF- $\beta 1, C o l$ $1 \alpha 2, T N F-a$ and iNOS genes

There were significant increases in hepatic mRNA expressions of $\alpha$-SMA, TGF- $\beta 1$, Col $1 \alpha 2$, TNF- $\alpha$ and iNOS genes relative to G3PDH in DMN rats compared with control rats (Figures $5 \mathrm{a}$ and $\mathrm{b}$ ). The mRNA expression levels of TGF- $\beta 1$ and $\alpha$-SMA in DMN rats were reduced by thalidomide treatment (Figure 5a). Moreover, the mRNA expression levels of Col $1 \alpha 2$, TNF- $\alpha$ and iNOS were attenuated by treatment of silymarin and high-dose thalidomide (Figures 5a and b).

\section{Discussion}

In the present study, we observed in vitro that (a) thalidomide concentration-dependently attenuated TGF- $\beta 1$-stimulated $\alpha$-SMA secretion and collagen deposition in HSC-T6 cells, (b) thalidomide also reduced TNF- $\alpha$ induced $\mathrm{NF \kappa B}$ activity, IKK $\alpha$ expression, I $\mathrm{K} \mathrm{B} \alpha$ phosphorylation, and collagen deposition in HSCs. To our knowledge, the present study was the first to demonstrate the in vitro inhibitory effects of thalidomide on TNF- $\alpha$-induced NFKB activity as well as collagen deposition, and TGF- $\beta 1$-stimulated fibrogenesis in a cell line of rat HSCs.

Our in vivo study showed that hepatic fibrosis scores, collagen contents, and mRNA expressions of $\alpha$-SMA, TGF- $\beta 1$, collagen $1 \alpha 2$, TNF- $\alpha$ and iNOS genes, of livers from DMN-treated rats with high-dose thalidomide were significantly reduced in comparison with those of DMN-treated rats receiving vehicle, together with reduction of hepatic injury markers (plasma AST activities). In the present study, high-dose thalidomide treatment $(200 \mathrm{mg} / \mathrm{kg})$ prevented the decrease in liver weight, but did not prevent the increase in spleen weight in DMN-treated rats. We speculate that high-dose thalidomide treatment prevented the decrease in liver weight, suggesting the amelioration of hepatic injury and fibrosis in DMN-treated rats. But thalidomide treatment did not prevent the increase in spleen weight, suggesting that portal hypertension-related splenomegaly following hepatic fibrosis may take longer to be ameliorated in DMN-treated rats. Further studies with longer duration of thalidomide treatment and measurement of hemodynamic parameters are needed to clarify this issue. Plasma ALT activities in DMN rats tended to be decreased by both lowdose ( $83 \pm 6$ vs. $108 \pm 13 \mathrm{U} / 1, p=0.09)$ or high-dose $(87 \pm 10$ vs. $108 \pm 13 \mathrm{U} / 1, p=0.15)$ treatment of thalidomide as compared with the vehicle group (Table 1), and the significance of thalidomide on plasma ALT activities (an indicator of heptocellular damage) could be under-powered by the limited number of rats in this study. Moreover, from the results of immuno-fluorescence double staining for $\alpha$-SMA and $\mathrm{NF \kappa B}$, we found that $\mathrm{NF \kappa B}$ translocated into the nucleus of $\alpha$-SMA-positive cells (activated HSCs), but not hepatocytes. In the DMN-thalidomide-treated rats, the number of $\alpha$-SMA-positive cells was significantly decreased. Overall, treatments with thalidomide $(200 \mathrm{mg} / \mathrm{kg})$ and silymarin $(50 \mathrm{mg} / \mathrm{kg})$ yielded comparable benefits in terms of reductions in collagen contents, $\alpha$-SMA expression and 

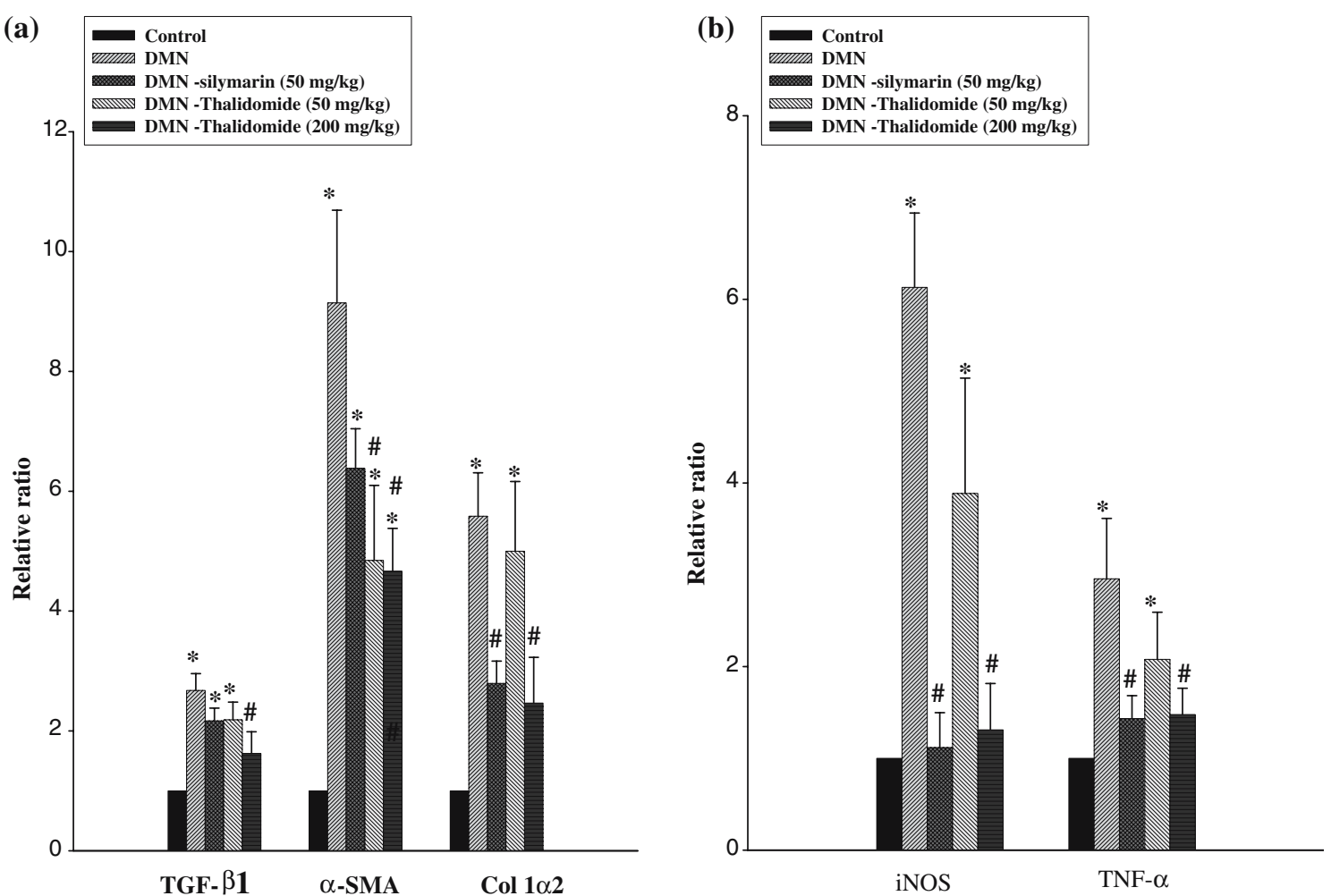

Figure 5. Quantitative real-time PCR analysis for the expressions of (a) TGF- $\beta 1$ (TGF- $\beta 1$ ), $\alpha$-SMA, and collagen $1 \alpha 2$ (Col $1 \alpha 2)$ gene transcripts, and (b) TNF- $\alpha$ and iNOS gene transcripts in control rats, DMN rats receiving vehicle, thalidomide $(40$ and $200 \mathrm{mg} / \mathrm{kg})$ or silymarin $(50 \mathrm{mg} / \mathrm{kg})$. The number of rats in each column is $8 .{ }^{*} p<0.05$ vs. the control group; ${ }^{\#} p<0.05$ vs. the DMN group receiving vehicle.

fibrosis-related mRNA expressions of collagen $1 \alpha 2$ and TNF- $\alpha$ genes. Nevertheless, thalidomide exerted better benefits than silymarin in terms of reduction in plasma AST activities indicative of hepatic injury, improvement of liver weight, and mRNA expressions of $\alpha$-SMA and TGF- $\beta 1$ genes.

TGF- $\beta 1$ has been viewed as a key mediator in hepatic fibrogenesis [1-4]. In our previous study [29], we observed that TGF- $\beta 1$ at $1.0 \mathrm{ng} / \mathrm{ml}$ was optimal for fibrogenic activation without inadvertent cytotoxicity; therefore, we chose this concentration for the present in vitro study and evaluated the inhibitory effects of thalidomide. Helm et al. [42] proposed that collagen biosynthesis may be an appealing target of thalidomide action. A non-sedative metabolite of thalidomide, 2-phthalimidoglutarimide, may inhibit the enzyme prolyl hydroxylase which catalyses the formation of 4-hydroxyproline in collagens. This proposed mechanism may contribute to the anti-fibrogeneic actions of thalidomide in our in vitro and in vivo studies. In a previous study, Muriel et al. observed that administration of thalidomide in carbontetrachloride-induced cirrhotic rats can reduce the hepatic hydroxyproline content, lipid peroxidation, ALT, $\gamma$-GT and ALP levels [25]. In the present study using a different animal model, we additionally included $\alpha$-SMA protein expression, and mRNA expression of fibrosis-related genes including TGF- $\beta 1, \alpha$-SMA and collagen $1 \alpha 2$ for therapeutic evaluation of thalidomide. Our results corroborated the study by Muriel et al. Taken together, thalidomide exerts anti-fibrotic effects in both DMN and carbon tetrachloride intoxicated rats.

TNF- $\alpha$ has been proposed as a mediator with a variety of biological effects that include proinflammatory and immuno-regulatory properties [5-7]. Serum TNF- $\alpha$ and TNF- $\alpha$ mRNA levels, both in the liver and peripheral mononuclear cells, were found to be elevated in chronic hepatitis C patients [43], patients with alcoholic liver cirrhosis [44], and in rats with acute liver damage induced by carbon tetrachloride [45]. 
TNF- $\alpha$ is a potent inducer of NF $\kappa$ B, a key transcription factor that induces genes involved in inflammation, responses to infection, and stress. Activated HSCs predominantly express the classic NFкB p65:p50 complex [5-7]. Once activated, $\mathrm{NF} \kappa \mathrm{B}$ dimers are translocated to the nucleus wherein they stimulate the transcription of genes that carry $\mathrm{NF \kappa B}$ binding motifs, including genes encoding iNOS and intercellular adhesion molecule-1 (ICAM-1) [46]. In our in vitro study, we found that TNF- $\alpha(20 \mathrm{ng} / \mathrm{ml})$ did not upregulate the mRNA expression of TGF- $\beta 1$ in HSC-T6 cells. Although both TNF- $\alpha$ and TGF- $\beta 1$ are well-known activators of HSCs [1-4], and the mRNA expressions of TNF- $\alpha$ and TGF- $\beta 1$ genes were upregulated in hepatic fibrotic rats in the present study, our current in vitro results did not suggest that HSC activation by TNF- $\alpha$ would result in, or was mediated through, TGF- $\beta 1$ signaling pathways. Several studies showed that HSC activation is associated with elevated $\mathrm{NF \kappa B}$ activity $[12,13,47]$. In the present study, using double staining technique, we demonstrated the co-localization of $\mathrm{NF} \kappa \mathrm{B}$ with activated HSCs ( $\alpha$-SMA-positive cells) in the DMN-induced fibrotic rats. Our results suggested that $\mathrm{NF \kappa B}$ activation and translocation into the nucleus was observed in activated HSCs during hepatic fibrogenesis in vivo, the number of which was reduced by thalidomide treatment (Figure 3b).

Recently, thalidomide is shown to inhibit $\mathrm{NF} \kappa \mathrm{B}$ activity through suppression of $\mathrm{I} \kappa \mathrm{B}$ kinase activity in human $\mathrm{T}$ cell lymphocytes and human vascular endothelial cells [48]. The authors found that NFKB DNA binding activity is inhibited by thalidomide through a mechanism that involves the suppression of IKK activity. Moreover, with its ability to block $\mathrm{NF} \kappa \mathrm{B}$ binding, thalidomide also inhibits the expression of NFKB-dependent genes including IL-8, TRAF1, and c-IAP2. Our present results also showed that thalidomide significantly inhibited TNF- $\alpha$-induced IKK $\alpha$ expression and $\mathrm{I} \kappa \mathrm{B} \alpha$ phosphorylation in HSCs (Figures 2b and c).

TNF- $\alpha$-induced NF $\kappa$ B activity was also attenuated by thalidomide (Figure 2a). The ability of

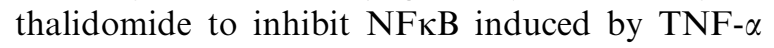
was transient, however, as suppression was partially lost at $9 \mathrm{~h}$. It remains to be clarified whether loss of in vitro activity could be partially due to the fact that thalidomide is labile to spontaneous hydrolysis in any aqueous solution [49]. Our previous study showed that TNF- $\alpha$ at 5, 10 and $20 \mathrm{ng} / \mathrm{ml}$ stimulated the NFKB luciferase activity in HSCs and the stimulated luciferase activity was higher at $20 \mathrm{ng} / \mathrm{ml}$, which was taken for the present studies on thalidomide.

There is another report showing that green tea polyphenol epigallocatechin-3-gallate (EGCG) also inhibits acetaldehyde-induced $\mathrm{NF} \kappa \mathrm{B}$ activity in HSCs [50]. One interesting difference between our study on thalidomide and the study on EGCG is that thalidomide affected the upstream signaling molecules of $\mathrm{NF} \kappa \mathrm{B}$, whereas EGCG reduces DNA binding ability of $\mathrm{NF} \kappa \mathrm{B}$ in HSCs.

The precise mechanisms of action of thalidomide remain to be clarified; however, the antifibrotic effects of thalidomide observed here might be partially due to its inhibitory effects on profibrotic and proinflammatory cytokines (e.g. TGF$\beta 1$ and TNF- $\alpha$ ). Whether thalidomide also exerted anti-fibrotic effects in DMN rats through other possible mechanisms such as protection of hepatocytes against apoptotic insults, another important but contrasting therapeutic strategy against liver fibrosis, remains to be explored [1-3, 51]. Although the side effects of thalidomide currently limit its clinical indications [20-23] and preclude the long-term use, efforts to synthesize thalidomide analogues lacking teratogenic effects but having more potent efficacy are underway [52]. Given that thalidomide has unique mechanisms of actions, there seems to be a strong possibility that this type of drug will also prove beneficial for patients with liver cirrhosis.

In conclusion, our results showed that thalidomide inhibited activation of HSC-T6 cells by TGF- $\beta 1$ and TNF- $\alpha$. Thalidomide treatment also exerted anti-fibrotic effects in DMN-induced fibrotic rats.

\section{Acknowledgements}

We gratefully acknowledge the kind provision of HSC-T6 cells by Dr. Scott L. Friedman, Division of Liver Diseases, The Mount Sinai School of Medicine, New York, NY, USA. We also cordially appreciate the supply of thalidomide by the TTY Biopharm Company Ltd. (Taipei, Taiwan). This work was supported in part by 
grants of the National Science Council, Taiwan (NSC 92-2320-077-006, NSC 93-2320-010-072 and NSC93-2320-010-001).

\section{References}

1. Friedman S.L., Liver fibrosis- from bench to bedside. J. Hepatol. 38: S38-S53, 2003.

2. Bataller R. and Brenner D.A., Liver fibrosis. J. Clin. Invest. 115: 209-218, 2005.

3. Pinzani M. and Marra F., Cytokine receptors and signaling in hepatic stellate cells. Semin. Liver. Dis. 21: 397-416, 2001.

4. Lotersztajn S., Julien B., Teixeira-Clerc F., Grenard P. and Mallat A., Hepatic fibrosis: molecular mechanisms and drug targets. Ann. Rev. Pharmacol. Toxicol. 45: 605-628, 2005.

5. Barnes P.J. and Karin M., Mechanisms of disease: Nuclear factor $\kappa \mathrm{B}-$ a pivotal transcription factor in chronic inflammatory diseases. N. Engl. J. Med. 336: 1066-1071, 1997.

6. Kumar A., Takada Y., Boriek A.M. and Aggarwal B.B., Nuclear factor $\kappa \mathrm{B}$ : its role in health and disease. J. Mol. Med. 82: 434 448, 2004.

7. Viatour P., Merville M.P., Bours V. and Chariot A., Phosphorylation of $\mathrm{NF} \kappa \mathrm{B}$ and $\mathrm{I} \kappa \mathrm{B}$ proteins: implication in cancer and inflammation. Trends Biochem. Sci. 30: 43-52, 2005.

8. Mercurio F., Zhu H. and Murray B.W., IKK-1 and IKK-2: cytokine-activated IkappaB kinases essential for NF-kappaB activation. Science 278: 860-866, 1997.

9. Zandi E., Rothwarf D.M., Delhase M., Hayakawa M. and Karin M., The IkappaB kinase complex (IKK) contains two kinase subunits, IKK alpha and IKK beta, necessary for IkappaB phosphorylation and NF-kappa B activation. Cell 91: 243-252, 1997.

10. Perkins N.D., The Rel/NFkappa B family: friend and foe. Trends Biochem. Sci. 25: 434-440, 2000.

11. Freedman A.R., Sharma R.J., Nabel G.J., Emarson S.G. and Griffin G.E., Cellular distribution of nuclear factor kappa B binding activity in rat liver. Biochem. J. 18: 63536364, 1992.

12. Hellerbrand C., Jobin C., Limuro Y., Licato L., Sartor R.B. and Brenner D.A., Inhibition of NFkappa B in activated rat hepatic stellate cells by proteasome inhibitors and an IkappaB superrepressor. Hepatology 27: 1285-1295, 1998.

13. Lang A., Schoonhoven R., Tuvia S., Brenner D.A. and Rippe R.A., Nuclear factor kappa B in proliferation, activation, and apoptosis in rat hepatic stellate cells. J. Hepatol. 33: 49-58, 2000.

14. Saile B., Matthes N., El Armouche H., Neubauer K. and Ramadori G., The bcl, NF $\kappa$ B and p53/p21WAF1 systems are involved in spontaneous apoptosis and in the antiapoptotic effect of TGF- $\beta$ or TNF- $\alpha$ on activated hepatic stellate cells. Eur. J. Cell Biol. 80: 554-561, 2001.

15. Bradham C.A., Plumpe J., Manns M.P., Brenner D.A. and Trautwein C., Mechanisms of hepatic toxicity I. TNFinduced liver injury. Am. J. Physiol. 275:G387-G392, 1998.

16. Iimuro Y., Gallucci R.M., Luster M.I., Kono H. and Thurman R.G., Antibodies to tumor necrosis factor $\alpha$ attenuate hepatic necrosis and inflammation caused by chronic exposure to ethanol in the rat. Hepatology 26: 1530-1537, 1997.

17. Moreira A.L., Sampaio E.P., Zmuidzinas A., Frindt P., Smith K.A. and Kaplan G., Thalidomide exerts its inhibitory actions on tumor necrosis factor alpha by enhancing mRNA degradation. J. Exp. Med. 177: 1675-1680, 1993.

18. Sampaio E.P., Sarno E.N., Galilly R., Cohn Z.A. and Kaplan G., Thalidomide selectively inhibits tumor necrosis alpha production by stimulated human monocytes. J. Exp. Med. 173: 699-703, 1991.

19. Deng L., Ding W.H. and Granstein R.D., Thalidomide inhibits tumor necrosis factor- $\alpha$ production and antigen presentation by Langerhans cells. J. Invest. Dermatol. 121: 1060-1065, 2003.

20. Ehrenpreis E.D., Kane S.V., Cohen L.B., Cohen R.D. and Hanauer S.B., Thalidomide therapy for patients with refractory Crohn's disease: an open-label trial. Gastroenterology 117: 1271-1277, 1999.

21. Reyes-Teran G., Sirrra-Madero J.G., Martinezdel Cerro V., Arroyo-Figueroa H., Pasquetti A. and Calva J.J., Effects of thalidomide on HIV-associated wasting syndrome: a randomized, double-blind, placebo-controlled clinical trail. AIDS 10: 1501-1507, 1996.

22. Stevens R.J., Andujar C., Edwards C.J., Ames P.R., Barwick A.R. and Khamashta M.A., Thalidomide in the treatment of the cutaneuous manifestation of lupus erythematous: experience in sixteen consecutive patients. Br. J. Rheumatol. 36: 353-359, 1997.

23. Volgelsang G.B., Farmar E.R., Hess A.D., Altamonte V., Beschorner W.E. and Jabs D.A., Thalidomide for the treatment of chronic graft versus host disease. N. Eng. J. Med. 326: 1055-1058, 1992.

24. Enomoto N., Takei Y., Hirose M., Ikejima K., Miwa H. and Kitamura T., Thalidomide prevent alcohol injury in rats through suppression of Kupffer cell sensitization and TNF- $\alpha$ production. Gastroenterology 123: 291-300, 2002.

25. Muriel P., Frenandez-Martinez E., Perez-Alvarez V., LaraOchoa F., Ponce S. and Garcia J., Thalidomide ameliorates carbon tetrachloride induced cirrhosis in rats. Eur. J. Gastroenterol. Hepatol. 15: 951-957, 2003.

26. Yeh T.S., Ho Y.P., Huang S.F., Yeh J.N., Jan Y.Y. and Chen M.F., Thalidomide salvages lethal hepatic necroinflammation and accelerates recovery from cirrhosis in rats. J. Hepatol. 41: 606-612, 2004.

27. Fernandez-Martinez E., Morales-Rios M.S., Perez-Alvarez V. and Muriel P., Effect of thalidomide and 3-phthalimido3-(3,4-dimethoxyphenyl)-propanamide on bile duct obstruction - induced cirrhosis in rat. Drug Dev. Res. 54: 209-218, 2001.

28. Vogel S., Piantedosi R., Frnak J., Lalazar A., Rockey D.C., Friedman S.L. and Blaner W.S., An immortalized rat liver stellate cell (HSC-T6); a new cell model for the study of retinoid metabolism in vitro. J. Lipid. Res. 41: 882-893, 2000.

29. Hsu Y.-C., Lin Y.-L., Chiu Y.-T., Shiao M.-S., Lee C.-Y. and Huang Y.-T., Anti-fibrotic effects of Salvia miltiorrhiza on dimethylnitrosamine-intoxicated rats. J. Biomed. Sci. 12: 185-195, 2005.

30. Park S.G., Ryu H.M., Lim S.-O., Kim Y.-I., Soon B., Hwang S.B. and Jung G., Interferon- $\gamma$ inhibits hepatitis B virus-induced $\mathrm{NF}-\kappa \mathrm{B}$ activation through nuclear localization of NF-кB-inducing kinase. Gastroenterology 128: 2042-2053, 2005. 
31. Alpert D. and Vilček J., Inhibition of $I \kappa B$ kinase activity by sodium salicylate in vitro does not reflect its inhibitory mechanism in intact cells. J Biol. Chem. 275: 10925-10929, 2000.

32. Yang F., Oz H.S., Barve S., De Villiers W.J.S., Mcclain C.J. and Varilek G., The green tea polyphenol (-)-epigallocatechin-3-gallate blocks nuclear factor- $\kappa \mathrm{B}$ activation by inhibiting $\mathrm{I} \kappa \mathrm{B}$ kinase activity in the intestinal epithelial cell line IEC-6. Mol. Pharmacol. 60: 528-533, 2001.

33. Williams E.J., Benyon R.C., Trim N., Hadwin R., Grove B.H., Arthur M.J.P., Unemori E.N. and Iredale J.P., Relaxin inhibits effective collagen deposition by cultured hepatic stellate cells and decreases rat liver fibrosis in vivo. Gut 49: 577-583, 2001.

34. Shiba M., Shimizu I., Yasuda M., Ii K. and Ito S., Expression of type I and type III collagens during the course of dimethylnitrosamine-induced hepatic fibrosis in rats. Liver 18: 196-204, 1998.

35. Hansen M.B., Nielsen S.E. and Berg K., Re-examination and further development of a precise and rapid dye method for measuring cell growth/cell kill. J. Immunol. Methods 119: 203-210, 1989.

36. Hsu Y.-C., Chiu Y.-T., Lee C.-Y., Lin Y.-L. and Huang Y.-T., Increases in fibrosis-related gene transcripts in livers of dimethylnitrosamine-intoxicated rats. J. Biomed. Sci. 11: 408-417, 2004.

37. Jezequel A.M., Mancini R., Rinaldesi M.L., Macarri G., Venturini C. and Orlandi F., A morphological study of the early stages of hepatic fibrosis induced by low doses of dimethylnitrosamine in the rat. J. Hepatol. 5: 174-181, 1987.

38. Lopez-De Leon A. and Rojkind M., A simple micromethod for collagen and total protein determination informalinfixed paraffin-emdeded sections. J. Histochem. Cytochem. 33: 737-743, 1985.

39. Sheuer P.J., Classification of chronic viral hepatitis: a need for reassessment. J. Hepatol. 13: 372-374, 1991.

40. Kitamura Y. and Ninomiya H., Smad expression of hepatic stellate cells in liver cirrhosis in vivo and hepatic stellate cell line in vitro. Pathol. Int. 53: 18-26, 2003.

41. Chomczynski P. and Sacchi N., Single-step method of RNA isolation by acid guanidinium thiocyanate- phenol-chloroform extraction. Anal. Biochem. 162: 156159, 1987.

42. Helm F.C., Frankus E., Friderichs E., Graudums I. and Flohe L., Comparative teratological investigation of compounds structurally and pharmacologically related to thalidomide. Arzneimittel-Forschung 31: 941-949, 1981.

43. Larrea E., Garcia N., Qian C., Civiera M.P. and Prieto J., Tumor necrosis factor alpha gene expression and the response to interferon in chronic hepatitis C. Hepatology 23: 210-217, 1996.

44. Rodriguez R.E., Gonzalez R.E., Santolaria F.F., Milena A.A., Rodriguez M.F. and Oramas R.J., Cytokines levels in acute alcoholic hepatitis: a sequential study. Drug Alcohol Depend. 39: 23-27, 1995.

45. Chamulitrat W., Blanzk M.E., Jordan S.J., Luster M.I. and Mason R.P., Tumor necrosis factor alpha and nitric oxide production in endotoxin-primed rats administered carbon tetrachloride. Life Sci. 57: 2273-2280, 1995.

46. Ghosh S., May M.J. and Kopp E.B., NF $\kappa B$ and rel proteins: evolutionary conserved mediators of immune responses. Annu. Rev. Immunol. 16: 225-260, 1998.

47. Wright M.C., Issa R., Smart D.E., Trim N., Murray G.I. and Prismrose J.N., Gliotoxin stimulates the apoptosis of human and rat hepatic stellate cells and enhances the resolution of liver fibrosis in rats. Gastroenterology 121: 685-698, 2001.

48. Keifer J.A., Guttridge D.C., Ashburner B.P. and Baldwin A.S. Jr., Inhibition of NF $\kappa \mathrm{B}$ activity by thalidomide through suppression of I $\mathrm{\kappa B}$ kinase activity. J. Biol. Chem. 276: 22382-22387, 2001.

49. Eriksson T., Bjorkmann S. and Hoglund P., Clinical pharmacology of thalidomide. Eur. J. Clin. Pharmacol. 57: 365-376, 2001.

50. Chen A., Zhang L., Xu J. and Tang J., The anti-oxidant (-)epigallocatechin-3-gallate inhibits activated hepatic stellate cell growth and suppresses acetaldehyde-induced gene expression. Biochem. J. 368: 695-704, 2002.

51. Canby A., Friedman S. and Gores G.J., Apoptosis: nexus of liver injury and fibrosis. Hepatology 39: 273-278, 2004.

52. Parman T., Free radical-mediated oxidative DNA damage in the mechanism of thalidomide teratogenicity. Nat. Med. 5: 582-585, 1999 . 